\title{
The Tejon Pass Earthquake of 22 October 1916: An M 5.6 Event on the Lockwood Valley and San Andreas Faults, Southern California
}

\author{
by Aron J. Meltzner* and Thomas K. Rockwell
}

\begin{abstract}
On 22 October 1916, a moderate earthquake occurred in the vicinity of Tejon Pass and was felt over much of southern California. An intriguing aspect of this event involves reports of ground cracks that formed during the earthquake. We evaluate the reports of ground cracking and attempt to precisely locate the cracks with respect to active faults; we infer that the earthquake produced minor fault rupture along a newly discovered trace of the easternmost Lockwood Valley fault (formerly mapped as the easternmost Big Pine fault) and/or along the San Andreas fault. We also re-evaluate and present new intensity data, and we use a grid-search algorithm (derived from empirical analysis of modern earthquakes) to find the magnitude most consistent with the reported intensities. Although previous authors have attempted to use intensity data to constrain the magnitude of this event, the algorithm we use provides an alternative and statistically more robust determination of the magnitude. Our results suggest $M 5.6(-0.3 /+0.2)$ (at $95 \%$ confidence) for the 1916 event, which is consistent with earlier work. The 1916 earthquake appears to have been a rare and remarkable event in terms of its size and location and the production of minor surface rupture.
\end{abstract}

\section{Introduction}

On 22 October 1916 at 18:44 PST, a moderate earthquake occurred in the vicinity of Tejon Pass (Fig. 1) and was felt over much of southern California. Palmer (1917) and Branner (1917) published reports and descriptions of the intensity at a number of locations, and Branner (1917) tentatively associated the earthquake with the San Andreas fault (SAF). One of the most intriguing aspects of this event is that several observers reported the formation of cracks, which in some cases may have been fault rupture.

In recent decades, several authors have studied this earthquake and have used various techniques to constrain its magnitude, although none have addressed the issue of potential fault rupture. The Gutenberg and Richter (1954) magnitude, which is generally based on surface waves, is $M_{\mathrm{G}-\mathrm{R}}$ $5.5 \pm$. Richter (1958) assigned a surface-wave magnitude of $M_{\mathrm{S}} 6$, but that magnitude was discounted as being too high by Stein and Hanks (1998); Stein and Hanks (1998) preferred a moment magnitude of $M_{\mathrm{W}} 5.3$ based on the seismic moment determined by Hanks et al. (1975). Toppozada and Parke (1982) estimated an intensity magnitude of $M_{\mathrm{I}} 5.2$ based on the areas shaken at modified Mercalli intensity (MMI) 5 and greater, but Toppozada et al. (2000) and Top-

*Present address: Division of Geological and Planetary Sciences, California Institute of Technology, Pasadena, California 91125; meltzner@ gps.caltech.edu pozada and Branum (2002) revised that figure up to $M_{\mathrm{I}} 5.5$. Ellsworth (1990) assigned a summary magnitude of $M$ 5.3.

In this study, we evaluate the reports of ground cracking and attempt to precisely locate the reported cracks with respect to active faults. We also reinterpret old felt reports, assess a newly found felt report from Ventura, and apply a grid-search algorithm to find the magnitude most consistent with the reported intensities. The algorithm, derived by Bakun and Wentworth $(1997,1999)$ from empirical analysis of modern earthquakes, is especially useful in cases where intensity data sets are sparse; in cases where the epicenter is known (e.g., because of fault rupture), it provides a statistically robust determination of $M_{\mathrm{I}}$.

The intensity data for our study come primarily from Branner (1917) and Toppozada and Parke (1982), although we found the following additional intensity information for the city of Ventura in the Daily Free Press of Ventura, California (23 October 1916, p. 1):

Clocks were stopped, dishes were rattled and lights put out in this city in one of the sharpest earthquake shocks felt here in many years, Sunday evening. Three distinct shocks were felt. The first occurred at 6:44, and the second a short interval thereafter; the third occurring at 6:55. People in the stores on Main street rushed to the street. No damage was done so far as reported. 


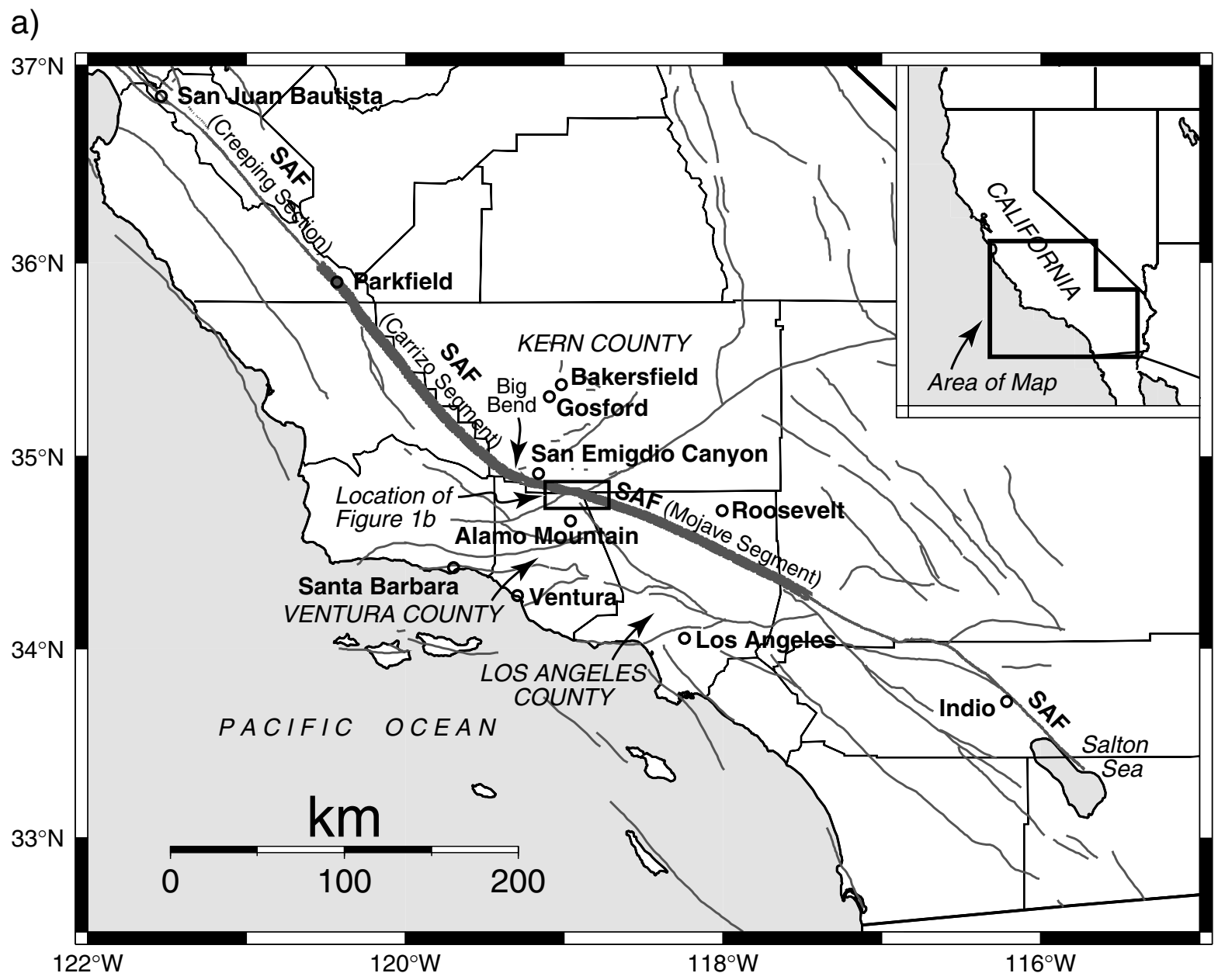

b)

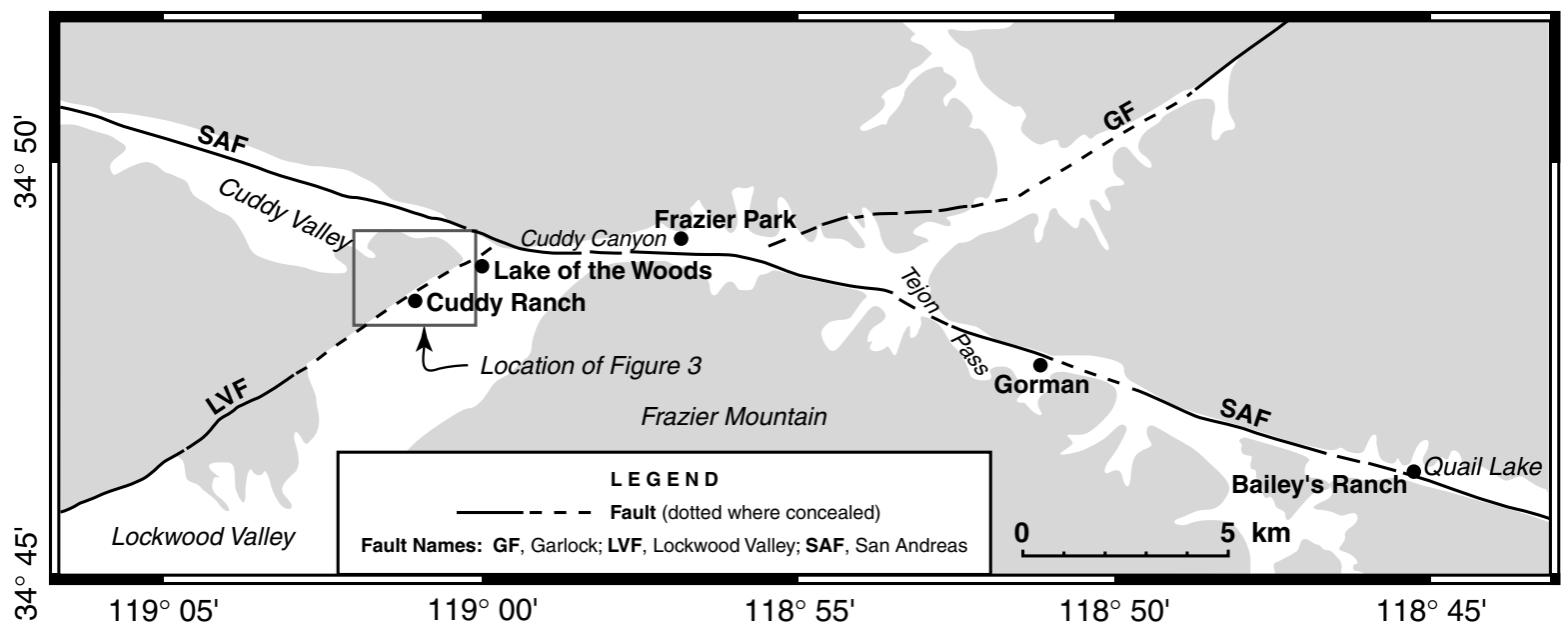

Figure 1. Maps showing locations discussed in the text. In (a), dark gray lines are faults, black lines are political or coastal boundaries, and lightly shaded areas designate water; the thick gray line is the 1857 rupture of the Carrizo and Mojave segments of the SAF. In (b), black lines are faults, and shaded areas represent mountains. Location of (a) shown on inset map, and location of (b) shown on (a). Faults in (b) simplified from Jennings and Strand (1969) and Kellogg (2003). See text for more information. 
This report is compatible with, but more elaborate than, previously published Ventura reports; see the Appendix for interpretation of the intensity.

We have re-examined each of the reports in Toppozada and Parke (1982); Figure 2 shows the distribution of intensity reports, which are listed in Table 1. Although in most cases we agreed with the intensities assigned by Toppozada and Parke (1982), in some cases we changed their intensity, and in a few cases we felt that the original report was not reliable enough to assign an intensity. The cases in which our interpretations disagree with theirs are discussed in the Appendix.

It is possible, given the observational data, that the SAF was at least partly involved in this earthquake. The SAF south of Parkfield is considered locked, and in modern times it has been nearly devoid of seismicity. Many authors have stated that the last significant event on the southern San Andreas was the 9 January $1857 M_{\mathrm{W}} 7.9$ Fort Tejon earthquake, which occurred on the Carrizo and Mojave segments of the fault. Yet if the 1916 event occurred on the SAF, it would be a striking exception to the general lack of intermediatesized earthquakes along that portion of the fault since 1857 .

Finally, we note that although earthquakes that are comparable in magnitude to the 1916 event rarely produce surface rupture, such earthquakes have been documented in modern times. Examples include the $1951 M_{\mathrm{L}}$ 5.6 Superstition Hills, California, earthquake, which produced $3 \mathrm{~km}$ of surface rupture with a maximum displacement of $\sim 5 \mathrm{~cm}$ (Allen et al., 1965); the $1975 M_{\mathrm{S}} 5.2$ Galway Lake, California, earthquake, which produced $6.8 \mathrm{~km}$ of surface rupture with a maximum displacement of $2 \mathrm{~cm}$ (Fuis, 1976; Hill and Beeby, 1977; Knuepfer, 1989); and the $1979 M_{\mathrm{S}} 5.6\left(M_{\mathrm{W}}\right.$ 5.55) Homestead Valley, California, earthquake, which produced $3.9 \mathrm{~km}$ of surface rupture with a maximum displacement of $10 \mathrm{~cm}$ and an average displacement of $5 \mathrm{~cm}$ (Hill et al., 1980; Stein and Lisowski, 1983); also see Wells and Coppersmith (1994). Each of these examples involved strike-slip faulting.

\section{Surface Rupture}

\section{Cuddy Ranch: Historical Observations}

Among the effects of the earthquake described in Branner (1917) are four reports of cracking that could describe fault rupture. The most compelling account comes from the original Cuddy homestead, in a statement taken from a report originally made by J. O. Marsh 22 days after the earthquake, on 13 November 1916 (see Branner, 1917, p. 57):

At the old Cuddy homestead in the south branch of the canyon ... we found a crack along the upper edge of a morass which was from two to six inches wide and about one hundred and fifty feet long, and which did not vary as much as a foot from a straight line. This crack was, for most of its length, on the side of a steep hillside about two to four feet above the level of the

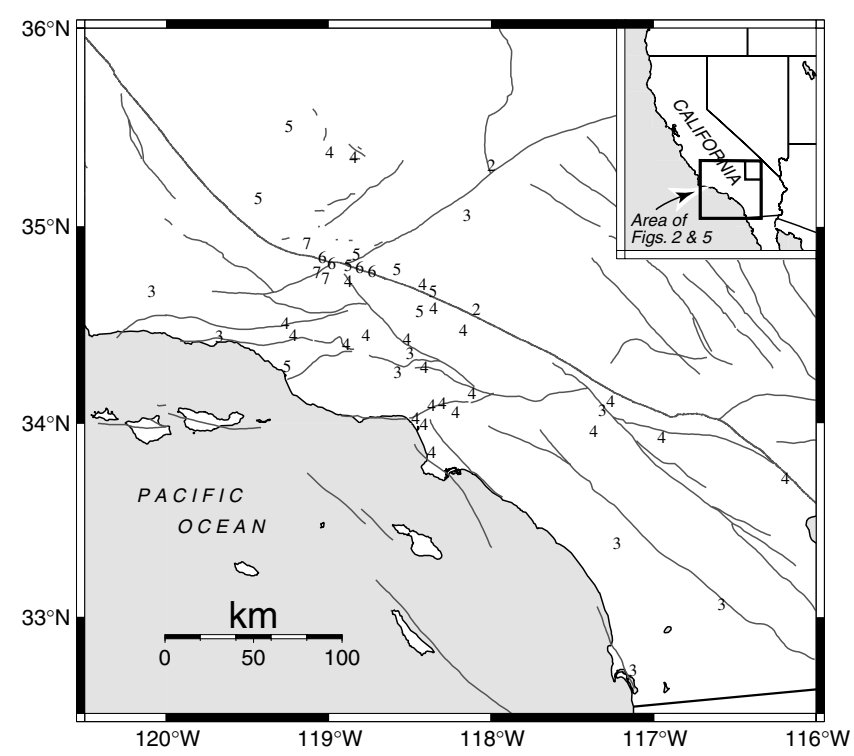

Figure 2. Map of intensities (numerals, which represent MMI values) for the 22 October 1916 Tejon Pass earthquake. See inset map for location.

morass, but for short distances it was in the bog, where the evidence was destroyed; but the people living there stated that after the quake the crack was continuous.

Branner (1917) does not provide any information as to the location of the Cuddy homestead, other than that it was in the south branch of Cuddy Canyon. There is no feature that is generally named or considered "the south branch of Cuddy Canyon," although an examination of topographic maps of the region reveals that the unnamed valley that straddles the present road between Lake of the Woods and Lockwood Valley is the only significant valley or canyon that branches to the south from Cuddy Canyon, and it is the only locale to which Mr. Marsh plausibly would have been referring (Fig. 1). On the 1943-1995 Cuddy Valley, California, 7.5' quadrangle U.S. Geological Survey (USGS) topographic maps, there is a site in this valley labeled "Cuddy Ranch" (Figs. 1, 3); at first glance, one might suspect that this site is the original Cuddy homestead.

Historical documents and local knowledge confirm our suspicion. Wagner (1880) shows the J. F. Cuddy house in T8N, R20W, Section 5, in essentially the same location as the Cuddy Ranch site on the 1943-1995 Cuddy Valley quadrangle topo maps. This information agrees with statements made by Mr. Marty Morehart, present owner of the Cuddy Ranch, and by Mrs. Ann Wride, a historian with the Ridge Route Communities Historical Society [RRCHS], to one of the authors (A.J.M.) that the house and log cabin that sit today on the Cuddy Ranch (see Figs. 3-4) are the original house and $\log$ cabin built in the 1850s-1860s by Mr. J. F. Cuddy, the namesake of Cuddy Valley and Cuddy Canyon (also see Wride, 2004). In light of the evidence, the site to which Branner (1917) referred as "the original Cuddy home- 
Table 1

Intensity Data

\begin{tabular}{|c|c|c|c|c|c|}
\hline Location & County & Latitude $\left({ }^{\circ} \mathrm{N}\right)$ & Longitude $\left({ }^{\circ} \mathrm{W}\right)$ & Possible MMI & Preferred MMI \\
\hline Fresno & Fresno & 36.748 & 119.771 & 3 & 3 \\
\hline Shafter & Kern & 35.501 & 119.271 & 5 & 5 \\
\hline Bakersfield & Kern & 35.373 & 119.018 & $4-5$ & 4 \\
\hline Edison & Kern & 35.348 & 118.871 & 4 & 4 \\
\hline Jawbone Canyon & Kern & 35.308 & 118.025 & $2-3$ & 2 \\
\hline Taft & Kern & 35.143 & 119.456 & $5-6$ & 5 \\
\hline Mojave & Kern & 35.053 & 118.173 & $2-3$ & 3 \\
\hline San Emigdio Canyon & Kern & 34.913 & 119.160 & $6-7$ & 7 \\
\hline Lebec & Kern & 34.842 & 118.864 & $5-6$ & 5 \\
\hline Cuddy Valley (R. C. Cuddy Ranch) & Kern & 34.836 & 119.046 & 6 & 6 \\
\hline Los Olivos & Santa Barbara & 34.668 & 120.114 & 3 & 3 \\
\hline Santa Barbara & Santa Barbara & 34.421 & 119.697 & 3 & 3 \\
\hline original Cuddy homestead (present Cuddy Ranch) & Ventura & 34.809 & 119.016 & 6 & 6 \\
\hline Frazier Borax Mine & Ventura & 34.768 & 119.088 & $6-7$ & 7 \\
\hline Snedden Ranch (Lockwood Valley) & Ventura & 34.734 & 119.043 & 7 & 7 \\
\hline Mr. Ford's Place & Ventura & 34.722 & 118.903 & $4-5$ & 4 \\
\hline Wheeler Springs & Ventura & 34.508 & 119.291 & 4 & 4 \\
\hline Ojai (Nordhoff) & Ventura & 34.448 & 119.242 & 4 & 4 \\
\hline 2 miles north of Piru Post Office & Ventura & 34.444 & 118.794 & 4 & 4 \\
\hline Fillmore & Ventura & 34.399 & 118.917 & 4 & 4 \\
\hline Ventura & Ventura & 34.278 & 119.292 & $4-5$ & 5 \\
\hline L. O. Chandler's (Tejon Pass) & Los Angeles & 34.811 & 118.884 & $4-5$ & 5 \\
\hline Gorman & Los Angeles & 34.796 & 118.852 & $5-6$ & 6 \\
\hline Neenach & Los Angeles & 34.783 & 118.606 & $5-6$ & 5 \\
\hline Bailey Ranch (near Quail Lake) & Los Angeles & 34.772 & 118.757 & $5-6$ & 6 \\
\hline Fairmont Reservoir & Los Angeles & 34.705 & 118.426 & 4 & 4 \\
\hline Elizabeth Lake & Los Angeles & 34.666 & 118.402 & $4-5$ & 5 \\
\hline Bouquet Reservoir* & Los Angeles & 34.583 & 118.380 & 4 & 4 \\
\hline Palmdale & Los Angeles & 34.579 & 118.116 & $2-3$ & 2 \\
\hline San Francisquito Canyon ${ }^{\dagger}$ & Los Angeles & 34.569 & 118.465 & $4-5$ & 5 \\
\hline Acton & Los Angeles & 34.470 & 118.196 & 4 & 4 \\
\hline Saugus & Los Angeles & 34.411 & 118.539 & 4 & 4 \\
\hline Newhall & Los Angeles & 34.385 & 118.530 & 3 & 3 \\
\hline San Fernando & Los Angeles & 34.282 & 118.438 & 4 & 4 \\
\hline Chatsworth & Los Angeles & 34.257 & 118.600 & 3 & 3 \\
\hline Pasadena & Los Angeles & 34.148 & 118.144 & 4 & 4 \\
\hline Hollywood & Los Angeles & 34.098 & 118.326 & 4 & 4 \\
\hline Sherman (near West Hollywood) & Los Angeles & 34.085 & 118.382 & 4 & 4 \\
\hline Los Angeles & Los Angeles & 34.052 & 118.243 & $4-5$ & 4 \\
\hline Santa Monica & Los Angeles & 34.019 & 118.490 & 4 & 4 \\
\hline Venice & Los Angeles & 33.991 & 118.459 & 4 & 4 \\
\hline Redondo Beach & Los Angeles & 33.849 & 118.388 & $4-5$ & 4 \\
\hline San Bernardino & San Bernardino & 34.108 & 117.289 & 4 & 4 \\
\hline Colton & San Bernardino & 34.074 & 117.313 & 3 & 3 \\
\hline Riverside & Riverside & 33.953 & 117.395 & 4 & 4 \\
\hline Beaumont & Riverside & 33.929 & 116.976 & 4 & 4 \\
\hline Indio & Riverside & 33.721 & 116.215 & 4 & 4 \\
\hline Fallbrook & San Diego & 33.376 & 117.250 & 3 & 3 \\
\hline Julian & San Diego & 33.079 & 116.601 & 3 & 3 \\
\hline San Diego & San Diego & 32.715 & 117.156 & 3 & 3 \\
\hline
\end{tabular}

*The location of both Tomson and Bynum Ranches are at the approximate present-day location of Bouquet Reservoir; Bouquet Reservoir is used here for both (see Bouquet Reservoir, California, 1937 6' USGS Topo Map).

$\dagger$ The location listed for San Francisquito Canyon is central to the best estimates of the locations of Spillway Camp and Camp 3.

stead" must be the site labeled "Cuddy Ranch" on modern USGS topographic maps (Figs. 1, 3); we shall hereinafter refer to this location as Cuddy Ranch.

The location of Cuddy Ranch coincides with the easternmost Lockwood Valley fault (LVF) (as mapped by Kel- $\operatorname{logg}$ [2003] and as shown on Figs. 1 and 3; formerly mapped as the easternmost Big Pine fault [e.g., Hill and Dibblee, 1953; Jennings and Strand, 1969]) and is $\sim 2 \mathrm{~km}$ southwest of the SAF (see Vedder and Wallace, 1970). One possible interpretation of this crack is that it was the result of sec- 


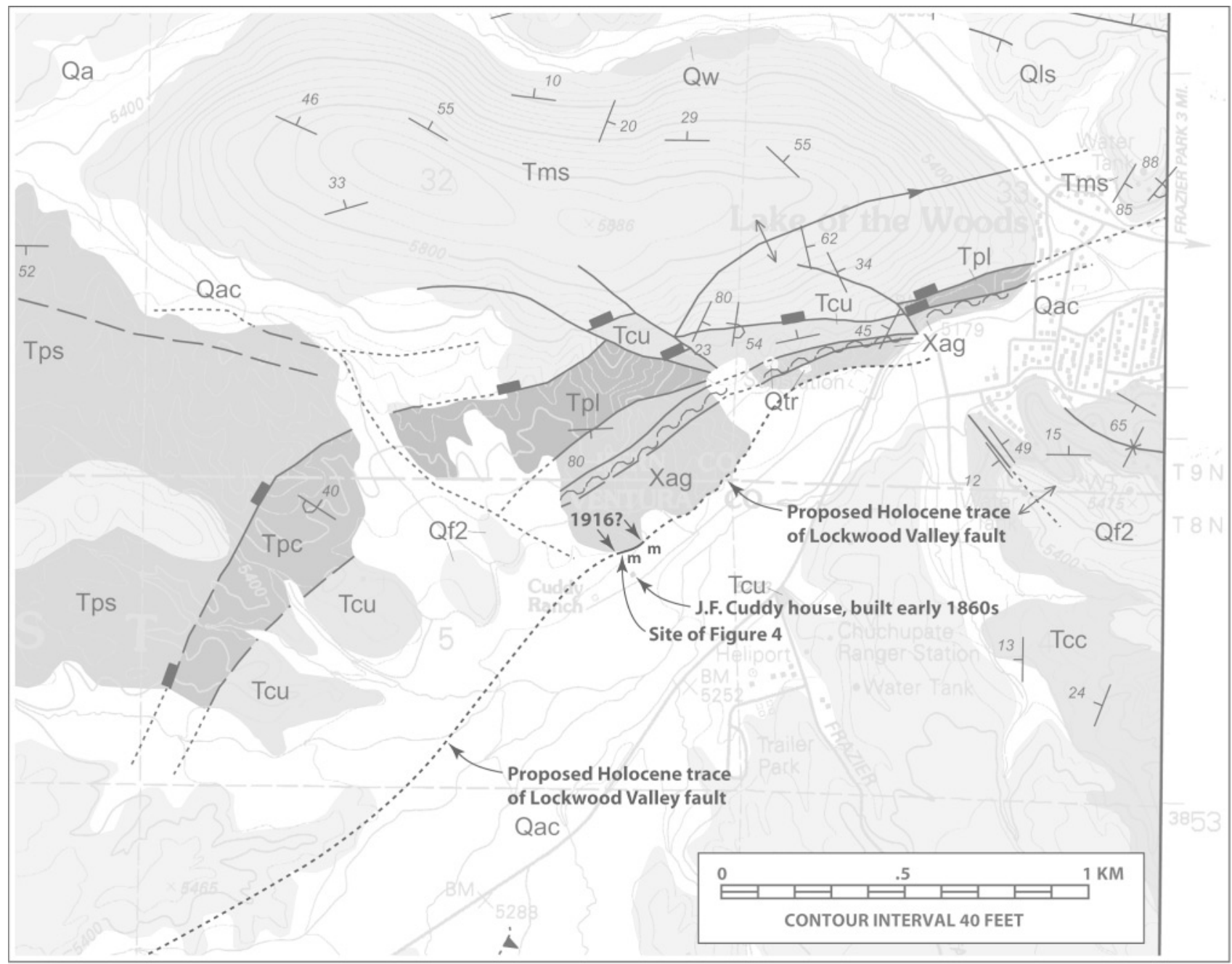

Figure 3. Portion of the geologic map of the Cuddy Valley quadrangle by Kellogg (2003) showing the vicinity of Cuddy Ranch and the active fault trace of the LVF proposed in this paper. The proposed site of faulting associated with the 1916 earthquake is the portion of the fault labeled "1916?"; the "m"s adjacent to the proposed 1916 rupture denote locations of wet areas observed during the January 2004 reconnaissance, although not all wet areas are so marked. All fault traces mapped by Kellogg (2003) are shown, with the exception of the trace that was inferred to run down the center of the valley, $\sim 100 \mathrm{~m}$ southeast of the Cuddy Ranch buildings; we have remapped this trace and show it in our preferred location. (It is labeled "Proposed Holocene trace of Lockwood Valley fault"; it is dashed where conjectural and solid where there is historical and geological evidence for its location.) See Kellogg (2003) for explanation of symbols and units, see Figure $1 \mathrm{~b}$ for location, and see text for further discussion.

ondary slumping or ground failure, but the observation that it followed a straight line irrespective of topography (it was apparent both midway up a steep slope and in a low-lying, relatively flat bog) tends to preclude such an interpretation. Although there is nothing in the report to suggest that there was any appreciable amount of slip, the remarkable linearity and the location of the crack suggest that it is a manifestation of fault movement, or at least that it was fault controlled.

\section{Cuddy Ranch: Geological Observations}

A geological reconnaissance of Cuddy Ranch and the vicinity was made by one of the authors (A.J.M.) in January 2004 in an attempt to locate the site described in Branner (1917). Specifically, the site would necessarily be along the base of a hill, at the (upper) edge of a morass, and portions of the morass near its intersection with the base of the hill would necessarily be wet, that is, it would necessarily be marshy or boggy, unless the site had been drained since 


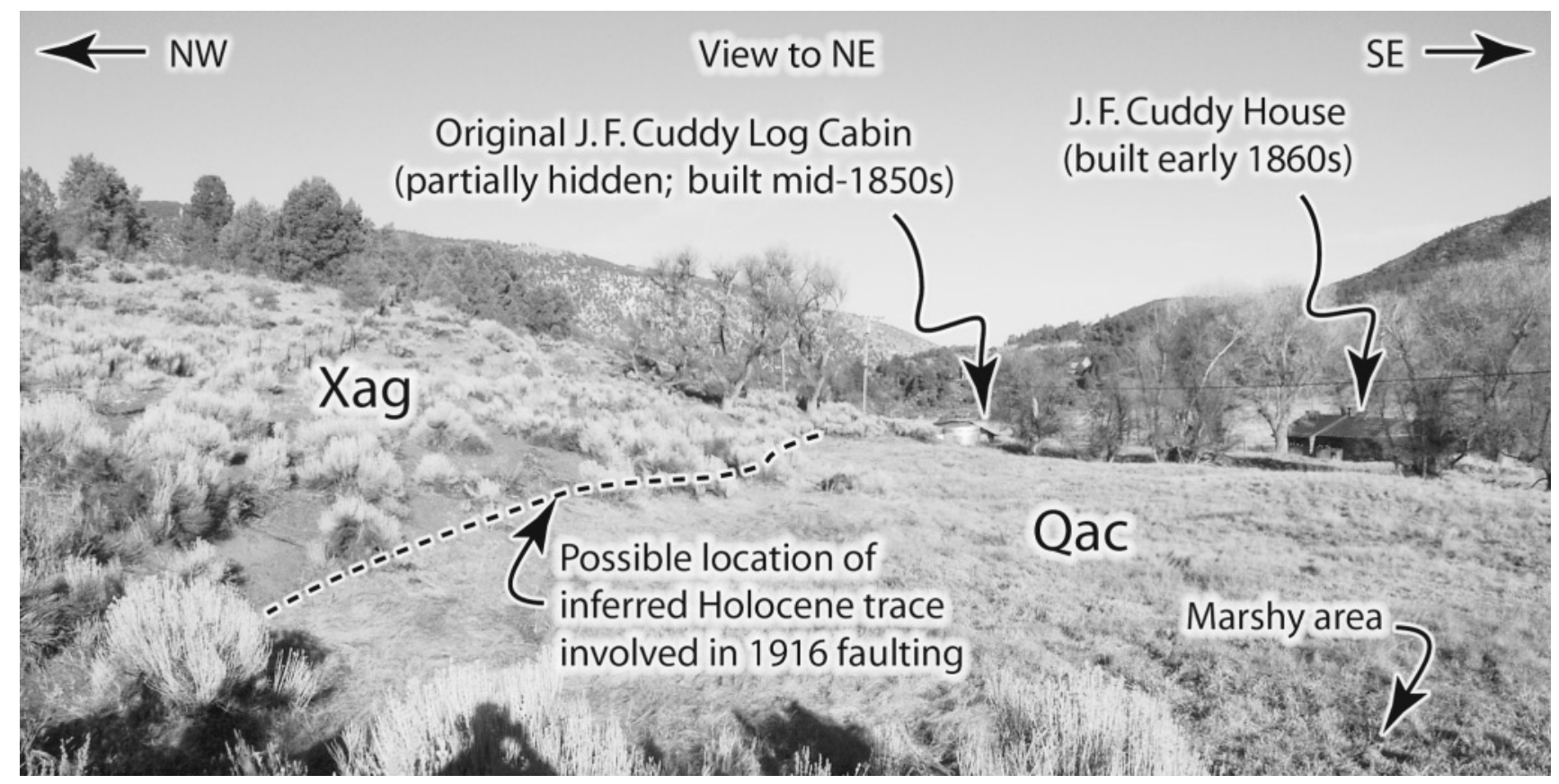

Figure 4. Photo showing a portion of the proposed fault trace that may have been involved in the 1916 faulting. Unit Xag, as mapped by Kellogg (2003), is Frazier Mountain augen gneiss (?), and Unit Qac is undivided Holocene alluvium and colluvium. The contact between the two units, shown as a dashed line, is interpreted in this article to be a young fault, based on the linearity of the contact and on the steepness of the slope just above the contact. Note that the site is the upper edge of a morass that extends to the southeast of the fault (to the right of the photo), and it is also the side of a (relatively) steep hillside (the hill mapped as Xag to the left or northwest). Note further that there are patches of ground southeast of the fault that are marshy or wet. Finally, note that the dashed line is about two to four feet above the level of the morass. All of these characteristics are consistent with the description of the site of observed cracking in 1916 as described in Branner (1917). For general location, see Figure 3.

1916. The reconnaissance was not restricted to locations of previously mapped faults, but if a site was found matching the requisite characteristics that was also along a mapped or possible unmapped fault trace, such a site would be preferred.

During the reconnaissance, the author identified a site that matches the description in Branner (1917). The site, which is labeled "1916?" on Figure 3 and part of which is shown in Figure 4, lies along the contact between a gneiss unit (mapped as Xag by Kellogg [2003]) and a unit consisting of Holocene alluvium and colluvium (mapped as Qac by Kellogg [2003]). In consideration of the description in the historical account, the site can be described as being both "the upper edge of a morass" (the part mapped as Qac) and "the side of a (relatively) steep hillside" (the part mapped as $\mathrm{Xag})$; in addition, the flatter area (Qac), though covered by grasses, was wet at the time of the reconnaissance (Figs. 34). Although the Xag-Qac contact has been mapped previously as a depositional contact, if it were in fact a fault, the fault could conceivably be "about two to four feet above the level of the morass," as described in Branner (1917).

Three lines of evidence support a conclusion that the
Xag-Qac contact is indeed a fault. First, this contact is fairly sharp, with a pronounced break in slope (it is steeper just above the contact), and portions of the contact are very linear. Even if the hypothesized scarp had been modified by anthropogenic means, there is still a relatively steep set of hills to the west and a much flatter area to the east that is most readily explained by the presence of a fault at this location. (There is no evidence for significant human modification of the ground surface, but in general, such evidence is not always easy to recognize.) The set of hills marked Xag immediately northwest of the hypothesized scarp may have been pushed up as a consequence of a restraining bend in the sinistral LVF (Fig. 3). Note, however, that even if our fault hypothesis is correct, the fault at this location could not have a high rate of vertical slip, as the Xag-Qac "range front" contact is considerably embayed.

Second, the standing water between the Cuddy house and the hypothesized scarp (Figs. 3-4) is apparently a perpetual feature that pre-dates possible human modification of the ground surface. According to Mr. Morehart, Mr. Cuddy originally settled at the site and built his home there in the 1850s because it is above the floodplain, and yet a natural 
seep provided a constant source of water. The occurrence of a spring in the immediate vicinity of the Xag-Qac contact adds credence to the hypothesis that the contact is a fault.

The third line of evidence supportive of a fault along the Xag-Qac contact is that Jennings and Strand (1969) and Kellogg (2003) infer a buried trace of the LVF to run down the center of the valley, between the Cuddy house and the road, although there are no good constraints on the location (K. Kellogg, personal comm., 2004). It is permissible, then (and in light of other evidence, it is plausible), that the inferred trace as mapped by Kellogg (2003) is $\sim 200 \mathrm{~m}$ too far to the southeast, and that the location shown in Figure 3 is more appropriate.

Altogether, historical evidence suggests that surface faulting occurred along the LVF at Cuddy Ranch in association with the 1916 earthquake, and geological observations permit such faulting to have occurred. Paleoseismic trenches at the proposed fault location might help validate this hypothesis, but they may not be conclusive. The sedimentation rate at the site appears, at a casual glance, to be low, and the comparatively high rainfall rate (relative to most of southern California) and the high potential for bioturbation of the near-surface layers (the site is on a ranch) make it likely that any evidence for young faulting has been overprinted by soil development and/or destroyed. At the very least, a trench could elucidate the nature of the Xag-Qac contact.

\section{Cuddy Ranch: More Historical Observations}

A second reference to cracking in Branner (1917) is more vague than the first and states only that on the west side of Frazier Mountain near J. D. Cuddy's ranch, "a crack opened in the ground." According to records held in the RRCHS Museum in Frazier Park, California, J. D. Cuddy was the son of J. F. Cuddy, and J. D. Cuddy took over his father's ranch (Cuddy Ranch) upon the elder's death in 1901; hence the J. D. Cuddy ranch was Cuddy Ranch. It appears, then, that this statement in Branner (1917) is a redundant reference to the crack that was discussed earlier.

\section{San Andreas Fault Sites}

Two other accounts in Branner (1917) come from farther east, along the SAF. In Gorman, "a crack opened several hundred feet long and an inch wide in the cement of the state highway," and at Bailey's Ranch, west of Quail Lake, "[t]he concrete on the state highway . . . is said to have been cracked" (see Fig. 1 for locations). Comparison of the 1903 Tejon, California, 1:125,000 quadrangle, the 1938 Gorman, California, 6' quadrangle, and the 1938 Quail, California, 6' quadrangle USGS topographic maps with Ross (1969) reveals that, in 1916, the state highway followed the SAF and either sat astride the fault or crossed it at very low angles, both near Gorman and $\sim 2 \mathrm{~km}$ west of Bailey's. Although we cannot rule out lateral spread or differential compaction (on either side of the fault) as the cause for the cracks at either location, fault rupture (including triggered slip) is, at the very least, a plausible explanation for the long, linear crack at Gorman and a possible explanation for the cracking near Bailey's. Once again, there is no evidence for an appreciable amount of coseismic slip. It is interesting to note that triggered slip or creep has not been observed along this portion of the SAF on any other occasion, although one must consider that the modern roads are built differently, and it is not clear whether they would sustain any noticeable damage from several millimeters or several centimeters of creep or triggered slip.

\section{Methodology for Intensity Analysis}

Bakun and Wentworth (1997, 1999) developed a method for the analysis of MMI values that results in an intensity magnitude $M_{\mathrm{I}}$ calibrated to equal moment magnitude $M_{\mathrm{W}}$ (Hanks and Kanamori, 1979). This method is an objective approach for analyzing intensity data, even for earthquakes for which only a small number of MMI values are known, and it provides objective uncertainties, empirically tied to confidence levels, for $M_{\mathrm{W}}$ and for source location. The method of analysis we used in this study is adapted from that of Bakun and Wentworth $(1997,1999)$. The modifications we made to their method are discussed in the appendix of Meltzner and Wald (1999): specifically, we did not employ Bakun and Wentworth's distance weighting function. The method can be summarized in the following three steps:

Step 1. Calculate the best magnitude, $M_{\mathrm{I}}$, at each point of a grid of trial source locations in the felt region. Here, $M_{\mathrm{I}}$ is the mean of $M_{i}$, and

$$
M_{i}=\left[\left(\mathrm{MMI}_{i}-\mathrm{C}_{i}\right)+3.29+\left(0.0206 \times \Delta_{i}\right)\right] / 1.68,
$$

where $\mathrm{MMI}_{i}$ is the MMI value at site $i, \Delta_{i}$ is the distance (in kilometers) from a trial source location to site $i$, and $\mathrm{C}_{i}$ is Bakun and Wentworth's (1997) empirical MMI correction for site $i$. Site corrections are not used in this study, so effectively, $\mathrm{C}_{i}=0$ for all $i$. Also compute the total rms error between observed and predicted intensities, $\operatorname{rms}\left[M_{\mathrm{I}}\right]$, for the magnitude, $M_{\mathrm{I}}$, at the trial source location. Here,

$$
\operatorname{rms}\left[M_{\mathrm{I}}\right]=\left[\operatorname{rms}\left(M_{\mathrm{I}}-M_{i}\right)-\mathrm{rms}_{0}\left(\mathrm{M}_{\mathrm{I}}-\mathrm{M}_{i}\right)\right]
$$

where $\mathrm{rms}_{0}\left(M_{\mathrm{I}}-M_{i}\right)$ is the minimum rms over the grid of trial source locations.

Step 2. The $\operatorname{rms}\left[M_{\mathrm{I}}\right]$ contours bound the epicentral region. The level of confidence can be assigned to each contour based on the number of MMI observations (e.g., table 1 in Meltzner and Wald [1999]). The trial source location for which $\operatorname{rms}\left[M_{\mathrm{I}}\right]$ is minimum is the point source of seismic energy that best satisfies the available intensity data (Bakun, 2000). This location, called the intensity center, corresponds more to the moment centroid than to the epicenter (Bakun, 
1999). Generally, the "best" or "preferred" source location is assigned based upon both the lowest $\operatorname{rms}\left[M_{\mathrm{I}}\right]$ contours and tectonic considerations; that is, we look for tectonically feasible locations (i.e., faults large enough to support a given earthquake magnitude) in light of the rms error contours. In cases such as the 1916 earthquake where the epicenter can be inferred from other information (such as possible faulting), the rms contours can be ignored, although they still provide an independent gauge of the quality of the "fit" of the data.

Step 3. The magnitude associated with a particular trial source location can be read from the magnitude contours for the grid, which appear as dotted black lines in Figure 5. In cases where the epicenter is known, $M_{\mathrm{I}}$ at the epicenter is the best estimate of $M_{\mathrm{W}}$ for the earthquake (e.g., Bakun, 2000). The statistical uncertainty in $M_{\mathrm{W}}$ appropriate for the desired level of confidence is taken from Bakun and Wentworth (1999) and is listed in Table 2.

\section{Location and Magnitude}

The algorithm solution for the 1916 event is shown in Figure 5. Based on the reports of probable minor fault rupture, the location of the epicentral region can be inferred independently of the rms error contours of the algorithm. Nonetheless, some comments on those contours are warranted. The rms error contours are elongated from southwest to northeast (Fig. 5). Such elongation of the location contours is not uncommon for historical data sets in California (e.g., Meltzner and Wald, 2003): if the epicentral location is well constrained by observations to the northwest and southeast but it is poorly constrained in the sparsely populated inland region and unconstrained offshore, then the location contours will be elongated in a direction perpendicular to the coastline. In other words, the elongation of those contours to the northeast and southwest is mostly an artifact of the irregular geographic distribution of the intensity data, and it is somewhat fortuitous that the intensity center is so close to the region of known surface rupture. Extrapolating from table 1 in Meltzner and Wald (1999), the 95\% confidence contour for 50 intensity data points corresponds roughly with the $0.1 \mathrm{rms}$ error contour. (Note that the confidence parameters for the rms contours listed in Bakun and Wentworth [1997 or 1999] are not valid in this case; see the appendix in Meltzner and Wald [1999] for further discussion.)

$M_{\mathrm{I}}$ in the region of the surface rupture is 5.6 (Fig. 5); incorporating the statistical uncertainty in the magnitude for 50 observations at $95 \%$ confidence (Table 2), our magnitude for this event is $M_{\mathrm{I}} 5.6(-0.3 /+0.2)$. Note that this value agrees well with the $M_{\mathrm{I}}$ of Toppozada et al. (2000) and Toppozada and Branum (2002). With the exceptions of Richter's (1958) magnitude (which was discounted as being too high by Stein and Hanks [1998]) and that of Toppozada and Parke (1982) (which has since been upgraded), our magnitude is consistent with all of the published magnitudes listed earlier.

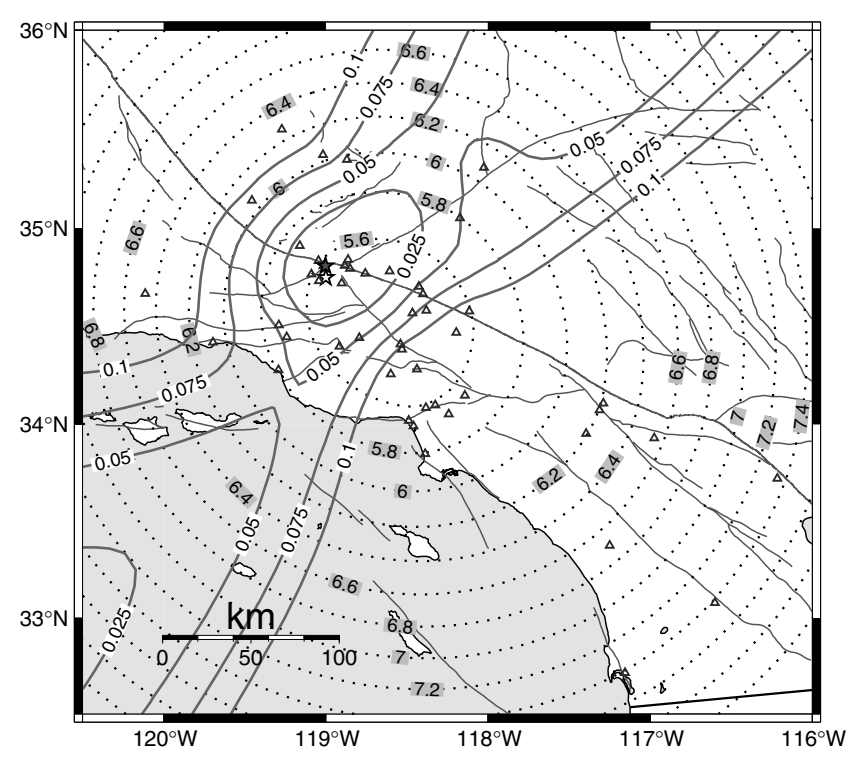

Figure 5. Map of the 1916 earthquake showing the algorithm's solution. Triangles designate locations of MMI data points. The 0.025, 0.050, 0.075, and $0.100 \mathrm{rms}\left[M_{\mathrm{I}}\right]$ contours are shown as solid lines. Extrapolating from table 1 in Meltzner and Wald (1999), the 95\% confidence contour for location (for 50 observations) corresponds roughly with the 0.1 rms error contour. The intensity center is a hollow star, and the inferred epicenter (the LVF at Cuddy Ranch) is a filled star. Contours of $M_{\mathrm{I}}$ are dotted lines. See inset map of Figure 2 for location.

\section{Discussion}

Based on the ground cracks discussed earlier, we propose that fault rupture (either primary or triggered) occurred on the LVF at Cuddy Ranch, on the SAF through Gorman, and possibly also on the SAF near Bailey's. It is not possible to determine how far the surface rupture continued in either direction from each of these points-given the small amount of slip that seems to have occurred (perhaps no more than a few centimeters), the rupture may have gone unnoticed in dense vegetation or tall grass, and it may have been promptly obliterated in places by grazing animals-but it seems improbable that the rupture was continuous between Gorman and the LVF, for several reasons. The foremost reason is that, in 1916 (as today), paved roads ran along much of the SAF between Quail Lake and San Emigdio Canyon, and these roads crossed the fault in multiple locations (see the 1903 Tejon and Mt. Pinos, California, 1:125,000 USGS topographic maps), yet no surface rupture was observed along the SAF west of Gorman. (Based on the careful documentation of Branner [1917], it is highly unlikely that surface rupture crossing a concrete highway would have been missed. The investigators invariably traversed the paved road between Quail Lake and Cuddy Ranch in their investigations and presumably would have noticed any substantial cracking were it present, although it is not known whether the investigators examined the road west of present-day 
Table 2

Confidence Parameters for Magnitude

\begin{tabular}{lccccc}
\hline \multirow{2}{*}{$\begin{array}{l}\text { No. of } \\
\text { MMI }\end{array}$} & $95 \%$ & $90 \%$ & $80 \%$ & $67 \%$ & $50 \%$ \\
\cline { 2 - 6 } 50 & $-0.30,+0.21$ & $-0.27,+0.19$ & $-0.22,+0.16$ & $-0.18,+0.13$ & $-0.13,+0.11$ \\
\hline
\end{tabular}

From Bakun and Wentworth (1999).

Lake of the Woods.) Another reason that continuous rupture between Gorman and the LVF is unlikely is that the LVF is mapped as a sinistral fault (Kellogg, 2003), whereas the SAF is dextral. A third reason is that Gorman and Bailey's are 14 and $23 \mathrm{~km}$, respectively, southeast of Lake of the Woods, and Cuddy Ranch is $\sim 2 \mathrm{~km}$ southwest of the SAF at Lake of the Woods. If the rupture was continuous and involved both the LVF (from Cuddy Ranch to the SAF) and the SAF (from the LVF to the southeast), then it would have been 16 $\mathrm{km}$ long if it extended only to Gorman and $25 \mathrm{~km}$ long if it extended to Bailey's. According to the empirical relations between magnitude and rupture length determined by Wells and Coppersmith (1994), the expected magnitude for an earthquake that produced $16-25 \mathrm{~km}$ of surface rupture would be $M_{\mathrm{W}} 6.5-6.7$ ( \pm 0.6 at $95 \%$ confidence), which is inconsistent with the other estimates of magnitude for this event.

A more likely explanation for the apparent observations of surface rupture is that primary rupture may have occurred on one of the faults, whereas triggered slip may have occurred a number of kilometers away on the other fault. (Many modern analogs exist for triggered slip at such distances [e.g., Rymer et al., 2002, and references therein].) Based on the highest intensities (MMI 7) in San Emigdio Canyon and at two locations in Lockwood Valley, all of which are near the LVF, we propose that primary fault rupture occurred on the LVF at Cuddy Ranch, and that triggered slip was produced on the SAF in Gorman and possibly at Bailey's; the opposite scenario-primary rupture on the SAF and triggered slip on the LVF-is also reasonable, but it would be less consistent with intensity data.

It is interesting to note that whether the primary rupture was left-lateral slip on the LVF or right-lateral slip on the SAF, the triggered slip cannot be readily explained by static triggering, in which there would be a decrease in the normal stress on the "triggered" fault caused by primary slip on the "primary" fault: sinistral slip on the LVF would have increased normal stress on the SAF to the east, and dextral slip on the SAF near Gorman would have increased normal stress on the LVF. Because the LVF and SAF intersect at such low angles $\left(\sim 45^{\circ}\right)$, however, it is conceivable that sinistral slip on the LVF could have affected shear stress and induced sinistral slip on the SAF, or by analogy, that dextral slip on the SAF could have induced dextral slip on the LVF. The $1983 M_{\mathrm{L}} 6.7$ Coalinga, California, earthquake apparently changed the stress field enough to induce submillimeter "backwards" left-lateral triggered slip on the SAF southeast of Parkfield (Mavko et al., 1985). In any case, if triggered slip did occur on either the SAF or LVF, it was most likely produced by a dynamic effect of passing surface waves, rather than by static triggering: given the distance between Cuddy Ranch and Gorman, the dynamic stresses at the site of triggering would likely have been an order of magnitude larger than the static stresses.

The 22 October 1916 Tejon Pass earthquake was a remarkable event in that it was a moderate event $\left(M_{\mathrm{I}} 5.6\right)$ that appears to have produced surface rupture (albeit probably secondary) on a characteristically locked portion of the SAF. As Hill et al. (1990) noted, there is a nearly complete absence of modern seismicity, down even to the smallest magnitudes $(M \approx 1.5)$, along the portions of the SAF that ruptured in 1857 and 1906 and along the southernmost section of the fault, from Indio to the Salton Sea, which last ruptured in a large earthquake in A.D. $1676 \pm 35$ (Sieh and Williams, 1990). Along the 1857 rupture, the Carrizo segment and the straight part of the Mojave segment have been almost completely aseismic in modern times, and although there have been a few earthquakes along the southernmost $80 \mathrm{~km}$ of the 1857 rupture zone, they appear to be on secondary fault structures rather than on the SAF itself (Hill et al., 1990). Within the area of the Big Bend of the SAF west of Tejon Pass, the level of modern seismicity is higher than in adjoining regions, but much of this activity is associated with the Pleito-White Wolf fault system and can be considered aftershocks of the 1952 Kern County earthquake (Hill et al., 1990). Toppozada et al. (2002) identified three events of $M$ $\sim 5.0-5.8$ in 1883, 1885, and 1919 (in addition to the event in 1916) that occurred in the vicinity of the SAF between Tejon Pass and the Big Bend, but limited intensity data preclude precise locations for these events. Aside from possibly 1916 and those events identified by Toppozada et al. (2002), no moderate (or larger) earthquake has been associated with the 1857 rupture since 1857.

Even at times when we might expect intermediate-sized earthquakes on the "locked" portions of the SAF-namely, during an aftershock sequence following a major SAF event-there seems to be a general lack of such seismicity. In the 5 years following the $1857 M_{\mathrm{W}} 7.9$ Fort Tejon earthquake on the southern SAF, there is no evidence for any $M$ $\geq 6$ aftershocks on the SAF, except for an $M \sim 6.2$ event that may have occurred on the SAF near or northwest of Parkfield in 1860 (Meltzner and Wald [1999]; Toppozada et al. [2000] 
and Toppozada and Branum [2002] have $M_{\mathrm{I}} 6.0$ for this event); in the 20 months following the $1906 M_{\mathrm{W}} 7.8$ San Francisco earthquake on the locked northern SAF, the only $M \geq 5.5$ aftershock that appears to have been on the SAF was an $M 5.6$ event near San Juan Bautista one month after the mainshock (Meltzner and Wald, 2003). Note that Parkfield is at the southern boundary of the creeping section of the SAF and has occasionally experienced $M \sim 6$ events, and that San Juan Bautista is at the northern boundary of the creeping section and has occasionally experienced $M \sim 5.5$ events (e.g., Hill et al. [1990]; Toppozada et al. [2000, 2002]; Toppozada and Branum [2002]). (Also note that it is not clear whether the post-1857 record is complete [Meltzner and Wald, 1999, 2003].)

The Tejon Pass mainshock was followed by a number of aftershocks, the largest of which occurred within 10-15 minutes and which was described in a few locations as being comparable in intensity to the initial shock. Toppozada and Branum (2002) estimate $M \sim 5$ for the largest aftershock; no additional analysis is performed here.

\section{Conclusions}

On 22 October 1916, an $M_{\mathrm{I}} 5.6(-0.3 /+0.2)$ (at $95 \%$ confidence) earthquake occurred in the vicinity of Tejon Pass, southern California, apparently producing minor surface rupture on the easternmost LVF and on the SAF. The rupture associated with the LVF is inferred to have been primary and the rupture associated with the SAF is inferred to have been triggered, although the reverse scenario is also possible. Based on historical observations and a geological reconnaissance of the inferred epicentral area, we believe the LVF rupture occurred on a previously unrecognized young trace of the fault at Cuddy Ranch, $\sim 2 \mathrm{~km}$ southwest of the SAF; rupture of the SAF may have occurred at Gorman and Bailey's Ranch. If primary rupture or triggered slip occurred on the SAF, it would have been a fairly unique occurrence on the Carrizo and Mojave segments of the SAF in historical times. The 1916 event challenges the hypothesis that the "locked" SAF does not sustain moderate earthquakes, or at least the hypothesis that it does not experience triggered slip.

\section{Acknowledgments}

We thank Tousson Toppozada for a helpful review of an early version of this article, and we thank Mike Rymer and an anonymous reviewer for thoughtful suggestions which led to substantial improvements and new findings. Our work benefited significantly from insightful discussions with Karl Kellogg, and we are very grateful for his assistance. We also wish to express our tremendous thanks to Marty Morehart, for providing access to Cuddy Ranch and for sharing his knowledge, and to Eloise Richer, Ann Wride, and the volunteers of the Ridge Route Communities Historical Society and Museum for sharing their knowledge and offering their assistance (and simply for their ongoing efforts to preserve the breadth of knowledge of local history). We wish to acknowledge the use of the Generic Mapping Tools software package by Wessel and Smith (1991) to generate parts of Figures 1, 2, and 5 in this report.

\section{References}

Allen, C. R., P. St. Amand, C. F. Richter, and J. M. Nordquist (1965). Relationship between seismicity and geologic structure in the southern California region, Bull. Seism. Soc. Am. 55, 753-797.

Bakun, W. H. (1999). Seismic activity of the San Francisco Bay region, Bull. Seism. Soc. Am. 89, 764-784.

Bakun, W. H. (2000). Seismicity of California's north coast, Bull. Seism. Soc. Am. 90, 797-812.

Bakun, W. H., and C. M. Wentworth (1997). Estimating earthquake location and magnitude from seismic intensity data, Bull. Seism. Soc. Am. 87, 1502-1521.

Bakun, W. H., and C. M. Wentworth (1999). Erratum to "Estimating earthquake location and magnitude from seismic intensity data" by W. H. Bakun and C. M. Wentworth, Bull. Seism. Soc. Am. 89, 557.

Branner, J. C. (1917). The Tejon Pass earthquake of October 22, 1916, Bull. Seism. Soc. Am. 7, 51-59.

Durham, D. L. (1998). California's Geographic Names: A Gazetteer of Historic and Modern Names of the State, Word Dancer Press, Clovis, California, 1676 pp.

Ellsworth, W. L. (1990). Earthquake history, 1769-1989, in The San Andreas Fault System, California, R. E. Wallace (Editor), U.S. Geol. Surv. Profess. Pap. 1515, 152-187.

Fuis, G. (1976). Ground breakage and aftershocks of the $\mathrm{M}_{\mathrm{L}}=5.2$ Galway Lake earthquake, June 1975, Mojave Desert, California, EOS 57, 954.

Gutenberg, B., and C. F. Richter (1954). Seismicity of the Earth and Associated Phenomena, Princeton University Press, Princeton, New Jersey, $131 \mathrm{pp}$.

Hanks, T. C., and H. Kanamori (1979). A moment magnitude scale, $J$. Geophys. Res. 84, 2348-2350.

Hanks, T. C., J. A. Hileman, and W. Thatcher (1975). Seismic moments of the larger earthquakes of the southern California region, Geol. Soc. Am. Bull. 86, 1131-1139.

Hill, D. P., J. P. Eaton, and L. M. Jones (1990). Seismicity, 1980-86, in The San Andreas Fault System, California, R. E. Wallace (Editor), U.S. Geol. Surv. Profess. Pap. 1515, 114-151.

Hill, M. L., and T. W. Dibblee (1953). San Andreas, Garlock, and Big Pine faults, California: a study of the character, history, and tectonic significance of their displacements, Geol. Soc. Am. Bull. 64, 443-458.

Hill, R. L., and D. J. Beeby (1977). Surface faulting associated with the 5.2 magnitude Galway Lake earthquake of May 31, 1975: Mojave Desert, San Bernardino County, California, Geol. Soc. Am. Bull. 88, 1378-1384.

Hill, R. L., J. C. Pechmann, J. A. Treiman, J. R. McMillan, J. W. Given, and J. E. Ebel (1980). Geologic study of the Homestead Valley earthquake swarm of March 15, 1979, Calif. Geol. 33, 60-67.

Jennings, C. W., and R. G. Strand "Compilers" (1969). Geologic Map of California, Los Angeles Sheet, scale 1:250,000.

Kellogg, K. S. (2003). Geologic map of the Cuddy Valley quadrangle, Kern and Ventura Counties, California, scale 1:24,000, U.S. Geol. Surv. Open-File Rept. 03-153, Version 1.0; available online at http:// pubs.usgs.gov/of/2003/ofr-03-153/ (last accessed June 2004).

Knuepfer, P. L. K. (1989). Implications of the characteristics of end-points of historical surface fault ruptures for the nature of fault segmentation, in Fault Segmentation and Controls of Rupture Initiation and Termination, D. P. Schwartz and R. H. Sibson (Editors), U.S. Geol. Surv. Open-File Rept. 89-315, 193-228.

Mavko, G. M., S. Schulz, and B. D. Brown (1985). Effects of the 1983 Coalinga, California, earthquake on creep along the San Andreas fault, Bull. Seism. Soc. Am. 75, 475-489.

Meltzner, A. J., and D. J. Wald (1999). Foreshocks and aftershocks of the great 1857 California earthquake, Bull. Seism. Soc. Am. 89, 11091120.

Meltzner, A. J., and D. J. Wald (2002). Felt reports and intensity assignments for aftershocks and triggered events of the great 1906 California earthquake, U.S. Geol. Surv. Open-File Rept. 02-37, 301 pp.; 
available online at http://geopubs.wr.usgs.gov/open-file/of02-37/ (last accessed June 2004).

Meltzner, A. J., and D. J. Wald (2003). Aftershocks and triggered events of the great 1906 California earthquake, Bull. Seism. Soc. Am. 93, $2160-2186$.

Palmer, A. H. (1917). California earthquakes during 1916, Bull. Seism. Soc. Am. 7, 1-17.

Richter, C. F. (1958). Elementary Seismology, W. H. Freeman and Company, San Francisco, California, 768 pp.

Ross, D. C. (1969). Map showing recently active breaks along the San Andreas fault between Tejon Pass and Cajon Pass, southern California, U.S. Geol. Surv. Misc. Investigations Series, Map I-553, scale $1: 24,000$.

Rymer, M. J., J. Boatwright, L. C. Seekins, J. D. Yule, and J. Liu (2002). Triggered surface slips in the Salton Trough associated with the 1999 Hector Mine, California, earthquake, Bull. Seism. Soc. Am. 92, 13001317.

Sieh, K. E., and P. L. Williams (1990). Behavior of the southernmost San Andreas fault during the past 300 years, J. Geophys. Res. 95, 66296645.

Stein, R. S., and T. C. Hanks (1998). $M \geq 6$ earthquakes in southern California during the twentieth century: no evidence for a seismicity or moment deficit, Bull. Seism. Soc. Am. 88, 635-652.

Stein, R. S., and M. Lisowski (1983). The 1979 Homestead Valley earthquake sequence, California: control of aftershocks and postseismic deformation, J. Geophys. Res. 88, 6477-6490.

Toppozada, T., and D. Branum (2002). California earthquakes of $\mathrm{M} \geq 5.5$ : their history and the areas damaged, in International Handbook of Earthquake and Engineering Seismology (Part A), W. H. K. Lee, H. Kanamori, P. C. Jennings, and C. Kisslinger (Editors), Academic Press, San Diego, California, 793-796 and CD-ROM.

Toppozada, T. R., and D. L. Parke (1982). Areas damaged by California earthquakes, 1900-1949, Calif. Div. Mines Geol. Open-File Rept. 8217 SAC, 65 pp.

Toppozada, T., D. Branum, M. Petersen, C. Hallstrom, C. Cramer, and M. Reichle (2000). Epicenters of and areas damaged by $M \geq 5$ California earthquakes, 1800-1999, Calif. Div. Mines Geol. Map Sheet 49, scale $1: 1,550,000$.

Toppozada, T. R., D. M. Branum, M. S. Reichle, and C. L. Hallstrom (2002). San Andreas fault zone, California: $M \geq 5.5$ earthquake history, Bull. Seism. Soc. Am. 92, 2555-2601.

Vedder, J. G., and R. E. Wallace (1970). Map showing recently active breaks along the San Andreas and related faults between Cholame Valley and Tejon Pass, California, U.S. Geol. Surv. Misc. Investigations Series, Map I-574, scale 1:24,000.

Wagner, T. [U.S. Surveyor General, California] (1880). Map of Township No. 8 North, Range No. 20 West, San Bernardino Meridian, scale $1: 31,680$. (Surveyed and published in 1880.)

Wells, D. L., and K. J. Coppersmith (1994). New empirical relations among magnitude, rupture length, rupture width, rupture area, and surface displacement, Bull. Seism. Soc. Am. 84, 974-1002.

Wessel, P., and W. H. F. Smith (1991). Free software helps map and display data, EOS 72, 441, 445-446.

Wood, H. O., and F. Neumann (1931). Modified Mercalli Intensity Scale of 1931, Bull. Seism. Soc. Am. 21, 277-283.

Wride, A. (2004). Cuddy cabin donated to museum, The Ridge Route Rambler (published by the Ridge Route Communities Historical Society, Frazier Park, California; E. Richer, Editor), Winter 2004, p. 1.

\section{Appendix}

Many of the original accounts that were used in our study to assign intensities were taken from appendix $\mathrm{C}$ of Toppozada and Parke (1982) (hereafter, T\&P). In an attempt to minimize the bias that is inherent in any reviewer's interpretation of intensities from historical accounts, we reinter- preted the reports in T\&P and assigned our own intensities, and then we compared our intensities with those of T\&P. While in most cases we agreed with their intensities, in some cases we differed, and in a few cases we felt that the original report was not reliable enough or that information was not sufficient to assign an intensity. All of our intensities are listed in Table 1. The cases in which our interpretations disagreed with those of T\&P are discussed in the following list. Note that the list does not include cases for which we assigned an intensity but T\&P did not.

Gosford (Kern Co.) - T\&P cited an article in the Bakersfield Californian, but the account is more fully explained in Branner (1917). We do not feel that the fact that a boxcar was moved 4 feet along a track by a shock is sufficient evidence for MMI 6; therefore, we do not assign an intensity.

Los Angeles (Los Angeles Co.) -While we feel that T\&P's assignment of MMI 5 is permissible by the account, we feel that MMI 4 is more appropriate. Most of the described effects, including the rattling of dishes, doors, windows, and window shades, the swaying of hanging lamps, and the creaking of ceilings and floors, suggest MMI 4 but nothing more. The "visible" disturbance of water in tumblers could support either MMI 4 or 5, depending upon how "visible" is interpreted. The awakening of a baby could also support MMI 4 or 5 , especially in light of the fact that most people would have been awake at the time of the earthquake. The fact that a few people ran outdoors might suggest MMI 5 , but the fact that the earthquake was not felt by persons in motion limits the intensity to MMI 4 . The overall majority of effects are consistent with MMI 4.

Roosevelt (Los Angeles Co.) - That a single person "was nearly thrown down" does not seem to be sufficient information to assign an intensity; thus, we do not assign one.

Surrey (Los Angeles Co.) - According to Durham (1998), the names Surrey and Saugus refer to the same location; the Surrey post office was renamed "Saugus" in 1915. This name change might explain why, two years later, Palmer (1917) referred to it as Surrey but Branner (1917) referred to it as Saugus. We use MMI 4 for the site, based on the account in Branner (1917) of dishes rattling.

Santa Barbara (Santa Barbara Co.) —Wood and Neumann (1931) listed "Pendulum clocks stopped, started, or ran fast, or slow" as characteristic of MMI 5; in contrast, Meltzner and Wald (2002, p. 299) observed that the stopping of clocks can also occur at lower intensities, that is, pendulum clocks are reported to have stopped when all other observations would indicate an intensity of MMI 4 or less. According to Branner (1917), in Santa Barbara, the 1916 earthquake was "observed by a few persons at rest," which would imply an intensity of no greater than MMI 3; the fact that some clocks were also stopped in Santa Barbara should not be considered in the determination of intensity for Santa Barbara.

Alamo Mountain, Frazier Mountain District, and Mr. Ford's Place (Ventura Co.)—Despite the fact that Wood and 
Neumann (1931) correlate the breaking of tree branches with MMI 8, we are skeptical that limbs falling from pine trees on Alamo Mountain is indicative of MMI 8. Likewise, we do not feel that small rockfalls are indicative of a particular intensity, because they can happen without an earthquake. In particular, T\&P assigned MMI $6+$ at Mr. Ford's Place, presumably based on the small rockfalls nearby, although the intensity at that place was "not severe enough to throw things off the shelves" (Branner, 1917); the latter observation suggests the intensity was no higher there than MMI 4 or 5. Thus, we assign MMI 4 at Mr. Ford's Place, and we do not assign an intensity at the other locations.

Wheeler Springs and 2 miles north of Piru Post Office (Ventura Co.) - At both locations, people were startled, but apparently no damage occurred; no other useful intensity information is presented for either location. T\&P assigned MMI 5 at Wheeler Springs but only MMI 4 at the location 2 miles north of Piru Post Office. For our own determination of the intensities, we felt that people being startled is indicative of a lower intensity than is people being frightened; for that reason, we assigned MMI 4 to both locations.
Ventura (Ventura Co.)—Although many people ran outdoors in Ventura, which would be indicative of MMI 6, the facts that there was apparently no damage and that not even dishes fell to the floor suggest that the intensity was no higher there than MMI 4 or 5. We assign MMI 5.

We also did not assign an intensity where the only basis would be a Rossi-Forel intensity assigned by Palmer (1917), and where there is no useful descriptive information from which we could independently assign a modified Mercalli intensity. This applied to Maricopa (Kern Co.); Fairmont and Mount Wilson (Los Angeles Co.); Gray Mountain and Redlands (San Bernardino Co.); and Ozena (Ventura Co.).

Department of Geological Sciences

San Diego State University

San Diego, California 92182

meltzner@gps.caltech.edu

trockwell@geology.sdsu.edu

Manuscript received 29 September 2003. 